\title{
Editorial
}

\section{The economics of long work hours: how economic incentives influence workplace practice}

In the four years from 2014 to 2017 , the number of fatal crashes involving large trucks in the United States increased by almost $24 \%{ }^{1)}$. This is not just a recent phenomenon, as the increase in truck-involved fatal crashes has been steady since 2009- the beginning of the recovery from the Great Recession. Between 2009 and 2017, fatal crashes involving large trucks increased $40 \%$. This was not just due to an increase in economic activity during the economic recovery; fatal crashes increased $45 \%$ per vehicle mile traveled (VMT) during this same period ${ }^{2}$.

Efforts to reduce commercial motor vehicle crashes and crash fatalities are not having the desired effect. Millions of dollars have been expended to reduce the death toll, yet the death toll continues to rise. This editorial suggests that researchers have paid insufficient attention to the market for freight transport ${ }^{\text {a) }}$. Intense competition, spawned by regulatory liberalization that began in the late 1970s, created an intense competition for revenue. Deregulation allowed cargo owners ${ }^{\text {b) }}$ to drive freight rates down ${ }^{3)}$. This saved consumers money but at the expense of trucking companies, truck drivers, and road users. Continued lighttouch regulation in the U.S. and in Europe ${ }^{4)}$ has allowed trucking companies to reduce freight rates, increasing trucking's share of freight transport.

The cost imposed on society is quite concrete. The rapid growth in package delivery service - accelerating in 2020 due to the COVID-19 pandemic - has provided an object lesson. Perhaps most famously, Amazon has successfully passed the cost of "fast free shipping" to the public by subcontracting much of their fast low-cost freight delivery. The Amazon business model shifts risk of low-cost shipping from Amazon to its contractors and subcontractors ${ }^{5)}$ as well as to the public.
The stress associated with work as a commercial motor vehicle (CMV) driver puts these drivers at significant health and safety risk. Drivers move on demand; that is, the truck moves when the freight is ready to move. This operational pressure leads to irregular work and rest schedules, and the competitive pressure provides a strong incentive for over-work; drivers who do not take a load that is offered may lose the freight and even lose their jobs. This, along with the low rates created by the same economic competition, also leads to excessively long work hours.

Customer pressure adds to this stress. Drivers operate within a framework requiring scheduled delivery that suits the cargo owner and not the trucker. Delivery must be fast, allowing cargo owners maximum flexibility to meet their competitive demands, and truckers must deliver at the lowest possible price. The Amazon pressure identified above exemplifies the stress on drivers, and the consequences of that stress.

Subcontracting creates competition among workers that allows logistics providers to take transport cost out of the market. Economists call these non-priced costs "externalities" because the costs are not incorporated into the price; they are external to the market. When a business externalizes health and safety risk, the cost escapes the pricing mechanism and market discipline. Workers pay the price for the risk in the form of occupational safety and health cost; the public pays the price in the form of public health and safety due to the high number of heavy truck crashes. The inequity leads to market inefficiency; society gets more of this economic activity than the market calls for, and hence more risk.

What is the social cost associated with this? One documented consequence is fatigue. Fatigue associated with

a) Commercial highway passenger transport has been similarly affected, as has been the rest of the commercial transport sector, but this research review will focus on trucking because it is a clear signal case within a single regulatory environment for which data and research analysis are robust. It also focuses on commercial motor vehicles-that is, CMVs used within a market for goods and services-because these vehicles are driven only for commercial purposes. This fits squarely within the purview of industrial and occupational safety and health. It also is consistent with the experience in airlines ${ }^{18)}$, as well as the ongoing investigation of the Boeing 737 Max and investigations of other major industrial accidents.

b) Owners of the freight to be transported.

This is an open-access article distributed under the terms of the Creative Commons Attribution Non-Commercial No Derivatives (by-nc-nd) License. (CC-BY-NC-ND 4.0: https://creativecommons.org/licenses/by-nc-nd/4.0/) 
this pressure leads to crashes and chronic illness. Stress and fatigue lead to CMV crashes, including injuries and deaths to public road users of all kinds ${ }^{6,7)}$, as well as the cost associated with these crashes. When safety and health costs are passed along to the public, this damages the market, the tax system, and drivers and passengers who fail to carry sufficient insurance coverage to protect themselves from the acts of others.

For all these reasons, workplace safety and health requires economic analysis. Indeed, root-cause analysis of CMV crashes and safety-critical events shows that they frequently have economic roots, and changes in the economic environment may be the most effective way to change the trend toward more crashes and health risks. How does this happen?

First, competition drives carriers to the lowest price. Low-price pressure drives carriers to cut cost as low as possible. This lowest-cost approach squeezes motor carriers to reduce driver pay - the cost over which they have the most control. This leads carriers to hire unqualified and dangerous drivers, and creates a separate pressure on the drivers to overwork - to work while impaired from fatigue. Second, primary carriers outsource to smaller carriers and individuals across all sectors of trucking. This subcontracting cuts employment cost while simultaneously adding layers of overhead cost. Subcontracting, for example, allows carriers to avoid the cost of liability, workers' compensation, avoid social payments (Social Security and Medicare for the U.S. and other social payments elsewhere). Third, it eliminates the risk that drivers might engage in "protected concerted activity"- union organizing, in the U.S. context - and any other concerted activity intended to ameliorate their situation. Subcontracting, therefore, contributes to worker health and safety risk $^{8,9)}$.

This editorial focuses on truck drivers because CMV driving is associated with substantial non-standard work and very long work hours worldwide ${ }^{10)}$. This is especially true for U.S long-distance drivers, whose work averages between 60 and $65 \mathrm{~h}$ per week. About $20 \%$ of these drivers work more than 75 h weekly ${ }^{11,12)}$. U.S. regulations prescribe a maximum of about $60 \mathrm{~h}$ per week, however, so how and why do drivers work so many hours?

The answer begins with a regulatory loophole: the U.S. Department of Labor (DOL) and the U.S. Department of Transportation Federal Motor Carrier Administration (FMCSA) define work differently for their regulations.
The DOL defines work as all time during which employees work for an employer, including waiting time ${ }^{13)}$. The FMCSA, on the other hand, defines work as time drivers are responsible for their freight. If carriers claim drivers are not responsible for the load while waiting, or loading and unloading, they can order drivers to log off duty and decline to pay for that work time ${ }^{14)}$. Since surveys show that CMV drivers average about $25 \%$ unpaid time, they underreport working time systematically.

A basic principle underlying economic theory is that "time is money". That is, if workers are not paid for all their time, and their allowable time is limited, they will make the rational choice not to report all work time; they accept the DOT definition of work that determines their earnings ${ }^{\mathrm{c}}$. This basic principle tells us that truck drivers (like everyone else) will trade labor for leisure if their pay rate is high enough. We tested that theory using individual employee driver data ${ }^{11)}$ and found that indeed, drivers will reduce their labor as their pay rate increases. Once they reach target earnings ${ }^{\mathrm{d})}$ they will reduce their working time, at the margin. Only at about 60 cents per mile will their preference for work decline to $60 \mathrm{~h}$ weekly; this earnings level allows them to make enough money to pay their bills ${ }^{15)}$.

Long-distance truck drivers therefore can work extremely long hours because regulatory enforcement is weak, despite the requirement that these trucks have electronic logbooks. A majority of these drivers earn no compensation for non-driving labor, so they record this work off duty. Second, they work long hours to pay their bills. That is, their rate of pay is low and based on "piecework" - by distance traveled. They may even earn money only for loaded miles-revenue miles-because their trucking company only pays them when they are earning revenue for the company. After long-distance truck drivers reach their target earnings, at the margin they decline additional work as they trade labor for leisure. Unfortunately, truck driver earnings have been so low for decades that the average rate of pay would have to be $50 \%$ greater than it is now to create an incentive for truck drivers to reduce hours of work to 60 per week $^{15)}$. Thus, low pay is the cause of this health and safety problem and that has to change to reduce CMV drivers' long work hours and risk.

Subsequent research has confirmed this conclusion, using the 2010 U.S. NIOSH National Survey of Long Haul Truck Driver Health and Injury (LHTDS). This research

c) "Earnings" is the sum of company payroll divided by total hours worked during a given period.

d) "Target earnings" is the amount drivers need to earn to pay their bills.

Industrial Health 2020, 58, 399-402 
tested two hypotheses. First, do truck driver pay rates predict the drivers' number of moving violations? Using a negative binomial regression, we found that the driver's pay rate and motor carrier's payment for health insurance predict that the number of moving violations the driver reports ${ }^{16)}$. At the margin, a higher pay rate and health insurance payments are associated with fewer moving violations.

In a similar project, we used the NIOSH LHTDS to test the hypothesis that unpaid labor time leads drivers to work excessive hours. We found that drivers who are paid for their non-driving work time will work fewer hours. This suggests that drivers who are paid for all their work are more likely to reduce work hours and therefore be less likely to have crashes due to fatigue ${ }^{17)}$.

The market for goods and services, which economics analyzes, is nothing more than a complex social system involving interactions locally and internationally among individuals within an institutional framework. It may be the most universal interaction around the world. The market is embedded into industrial health and safety and underlies the productive process that provides goods and services to society. It should be no surprise that market analysis provides us with a window into worker health and safety, making it an important analytic tool.

\section{References}

1) 2019 Pocket Guide to Large Truck and Bus Statistics (2020) https://rosap.ntl.bts.gov/view/dot/43602 and https:/www. fmcsa.dot.gov/safety/data-and-statistics/commercial-motorvehicle-facts.

2) Belzer MH The Economics of Long Work Hours: Using Incentives to Change Behavior. Keynote for TwentyFourth International Symposium on Shiftwork \& Working Time. September 11, 2019. Coeur d'Alene. https://www. eiseverywhere.com/file_uploads/5bf599c679bb4aac684 97c19b68d83ba_190911Belzer_EconOfFatigue.pdf. See also The economics of long work hours: using incentives to change behavior. Healthy Work Design and WellBeing National Occupational Research Agenda Cross Sector Program. April 23, 2020. National Institute for Occupational Safety and Health. Accessed August, 2020. https://www.cdc.gov/nora/councils/hwd/webinar.html [uses Adobe Flash].

3) Belzer MH (2000). Sweatshops on wheels: winners and losers in trucking deregulation. Oxford, UK and New York, Oxford University Press, New York.

4) Belzer MH, Thörnquist A (2020). Economic Liberalisation of Road Freight Transport in the EU and the USA. In Sheldon P, Gregson S, Lansbury R, Sanders K (Eds.), The regulation and management of workplace health and safety: historical and emerging trends (1st ed., 52-79). Routledge, New York.

5) The human cost of Amazon's fast, free shipping. NY Times. https://www.nytimes.com/2019/09/05/us/amazon-deliverydrivers-accidents.html; How Amazon hooked America on fast delivery while avoiding responsibility for crashes. ProPublica's Big Story. Accessed September 5, 2019. https://features.propublica.org/amazon-delivery-crashes/ how-amazon-hooked-america-on-fast-delivery-whileavoiding-responsibility-for-crashes/; The Cost of Next-Day Delivery. BuzzFeed. Accessed August 31, 2019. https:// www.buzzfeednews.com/article/carolineodonovan/amazonnext-day-delivery-deaths. Inside documents show how Amazon chose speed over safety in building its delivery network. ProPublica. Accessed December 23, 2019 https:// www.propublica.org/article/inside-documents-show-howamazon-chose-speed-over-safety-in-building-its-deliverynetwork.

6) Belzer MH (2018) Work-stress factors associated with truck crashes: an exploratory analysis. Econ Labour Relat Rev 29, 289-307.

7) Panel on Research Methodologies and Statistical Approaches to Understanding Driver Fatigue Factors in Motor Carrier Safety and Driver Health (2016). Commercial motor vehicle driver fatigue, long-term health, and highway safety: research needs. National Academies Press, Washington. https://www.nap.edu/download/21921.

8) Eurofound; Pedersini R, Pallini M 2016. Exploring the fraudulent contracting of work in the European Union. Luxembourg: European Foundation for the Improvement of Living and Working Conditions, 42. http://ec.europa.eu/ social/BlobServlet?docId=17225\&langId=en.

9) Quinlan M, Mayhew C, Bohle P (2001) The global expansion of precarious employment, work disorganization, and consequences for occupational health: a review of recent research. Int J Health Serv 31, 335-414. [Medline] [CrossRef]

10) Tripartite Sectoral Meeting on Safety and Health in the Road Transport Sector, Geneva, Switzerland: International Labour Organization (2015) https://www.ilo.org/sector/ activities/sectoral-meetings/WCMS_337096/lang-en/index. htm.

11) Belman DL, Monaco KA, Brooks TJ (2004). Sailors of the concrete sea: a portrait of truck driver' work and lives. Michigan State University Press, East Lansing.

12) Chen GX, Sieber WK, Lincoln JE, Birdsey J, Hitchcock EM, Nakata A, Robinson CF, Collins JW, Sweeney MH (2015) NIOSH national survey of long-haul truck drivers: injury and safety. Accid Anal Prev 85, 66-72. [Medline] [CrossRef]

13) Code of Federal Regulations (CFR) Title 29, Subtitle B, Chapter V, Subchapter B, Subpart C, Part 785 (Hours Worked) Subpart C (Application of principles). (2020) Cornell Law School Legal Information Institute, Itaca. https://www.law.cornell.edu/cfr/text/29/part-785/subpart-C. 
14) Code of Federal Regulations (CFR) Title 49, Subtitle B, Chapter III, Subchapter B, Part 395 Hours of Service of Drivers. (2020) United States Government Office of the Federal Register and the Government Publishing Office, Washington DC, https://www.ecfr.gov/cgi-bin/retrieve ECFR $? \mathrm{gp}=1 \&$ ty $=$ HTML $\& \mathrm{~h}=\mathrm{L} \& \mathrm{mc}=$ true $\&=$ PART $\& \mathrm{n}=$ pt49.5.395.

15) Belzer MH, Sedo SA (2018) Why do long distance truck drivers work extremely long hours? Econ Labour Relat Rev 29, 59-79.

16) Kudo T, Belzer MH (2019) The association between truck driver compensation and safety performance. Saf Sci 120, 447-55. [CrossRef]

17) Kudo T, Belzer MH (2019) Safe rates and unpaid labour: non-driving pay and truck driver work hours. Econ Labour Relat Rev 30, 532-48.

18) Young R (2010) Flying cheap. In Frontline \& American University School of Communication's Investigative Reporting Workshop (Producer). USA: PBS. http:// www.pbs.org/wgbh/pages/frontline/flyingcheap/?utm campaign $=$ homepage \&utm_medium $=$ proglist\&utm source $=$ proglist.

Michael H. BELZER

Department of Economics, Wayne State University, USA 